\title{
Questioning and Organization Studies
}

We are still a long way from having a complete and adequate theory of questions.

(Harrah, 1973, p. 450)

Kelemen, M., Rumens, N. Vo, L.

Accepted in Organization Studies (April, 2018)

\section{Introduction}

The role of questioning is central in our everyday lives, not least because all aspects of society have been subject to questioning. For instance, the topic of immigration is currently subject to questions about the flow of people across borders, exemplified in the Syrian refugee crisis and the proposed border wall between the US and Mexico. Questions are also designed to stir our curiosity, dramatized in films and novels, such as Who Killed Roger Rabbit?, Do Androids Dream of Electric Sheep? and Who's Afraid of Virginia Wolf? Elsewhere, questions motivate us to reflect on how we ought to live our lives at a time when we cannot rely upon the traditions of the past. Indeed, in modern societies that are frequently characterized in terms of 'uncertainty' and 'risk' (Beck, 1992), we are seemingly compelled to question everything: the family, intimacy, sex, identity, gender, sexuality, ethnicity, race, education, law, the medical profession and art, to mention but a few. Equally, questioning can inspire, startle and surprise us, 
illustrated by surreal photographer Erik Johansson's 'Questioning Architecture', which depicts a building in the form of a question mark, designed to provoke searching questions about the role of modern architecture in our lives. It is self-evident to assert that questioning is fundamental to how we make sense of our lives and the world around us, just as it is incontrovertible to reason that the role of questioning is pivotal in the research process and in everyday language use.

Yet, despite the ubiquity of questioning in our everyday lives, one problem is, as Harrah (1973) notes above, and as philosopher C.E.M. Struyker Boudier (1988) points out, 'there is no history of the question as such' (p. 9), although scholars have attended to the problem of the question. One observation is that questioning is so deeply naturalized within everyday routines and language use that it is rarely questioned. More than most, philosophers have recognized this omission, and have generated scholarly debate on questioning that has, as Turnbull (2014) reasons, largely focused on what the question is of' (p. 88, emphasis in original). Inspired by the philosophy of questioning, commentators in other disciplines have interrogated questioning as an object of study, an instrument of academic practice and as a practical pursuit (Dilon, 1982).

In organization studies, it occurs to us that there is a cleavage in the literature that separates 'questions' and 'questioning' at a very fundamental philosophical level. On the one hand, the objective notion of 'questions' has already been well addressed within organization studies, evident in how scholars have scrutinized questions as 
objects of analysis; for example, paying close attention to the forms and functions of questions as instruments of research. More recently, the linguistic turn within the social sciences has influenced how organization studies researchers have considered organizations as discursive entities, with debate extending to the discursive nature of 'questions'. On the other hand, the process of 'questioning' remains under-researched. From one perspective, questioning the process of questioning is challenging, but, as we submit, this is precisely where American pragmatism can be helpful. As we explore in this essay, the forward-looking quality of pragmatist inquiry is what motors the process of questioning. Our pragmatist-inflected argument is that questioning does not have to always serve critique and position building in the organization studies field. Rather, questioning out of curiosity can build new dialogue and open up new methodological avenues. This may help change the habitual ways in which we explore ideas, problems and situations in organization studies as well as lead to more democratic forms of organizing. Crucially, in this essay we are not looking for ultimate 'answers'; rather we hope to excite discussion about questioning by giving prominence to something that is so ubiquitous and taken-for-granted as to be invisible to many of us as an object of inquiry.

\section{Questioning in organization studies}

For many commentators, organizational thinking is no more, no less than a form of questioning. Indeed, without questioning, how can there ever be critique, dialogue or 
progress in any field of knowledge? We contend that questioning is deeply implicated in the critical imagination of organization studies scholars, their conceptualizations and methodological choices.

Taking critical imagination first, as early as 1959, C. Wright Mills called for theoretical and methodological creativity in order to respond to existing societal problems and affect change. At the heart of critical imagination is the practice of questioning. Barratt (2011, p. 708) puts it thus, questioning helps to 'distance familiar thinking from contemporary usage, returning ideas to the conditions and circumstances in which they first took shape'. This process comes close to what Derrida (1967[1978]) refers to as deconstruction, the act of close reading/questioning of foundational texts that shape a scientific discipline. It is not only a matter of questioning what may be missing from the text and or what the hidden conclusions could be; more importantly, it is about questioning how the text is put to work to elevate certain ideologies and downplay others. By questioning the ways in which seminal texts advance normative views in organization, one can start opening up avenues for emancipation and empowerment in the workplace. As Kilduff and Kelemen (2001) argue, the close questioning of March and Simon's seminal work Organisations (1958) which appears to offer a new model of work, supposedly far removed from Taylorist metaphors, leads to the realization that the machine analogy has in fact not been removed at all, but 
adapted to convey a new form of control in which employees had little power outside the recurring action patterns within which they are expected to work.

Typically referred to as routines, these repetitive action patterns have spurred the critical imagination of generations of organizational scholars (Feldman and Pentland, 2003; Cohen, 2007; Simpson and Lorino, 2016). Much of the organization studies field has focused on either the abstract and general nature of routines as a means to re-enact the past, or on their performative nature which ensures adaptability to new situations. Going beyond this dichotomy, Cohen's analysis (2007), which draws on John Dewey's notion of inquiry, shows that routines (or habits) are predispositions deeply implicated in both cognition and emotion. When the individual faces a challenge and cannot simply rely on habit, he/she will first engage his/her emotions and if this does not suffice, cognitive faculties will be drawn upon to question the situation and reconfigure it in a new format that may hopefully be successful in dealing with the challenge. A research focus on the dynamic interplay between habit, thought and emotion which sees the process of questioning as paramount, is for Cohen (2007) a more potent line of inquiry into processes of organizing than the separation from and elevation of cognition at the expense of both habit and emotion. While Cohen's position may seem bizarre, it alerts us to a richer worldview in which habits are as important to our behaviour as are cognitions and emotions. 
Elsewhere, Simpson and Lorino (2016) articulate a pragmatist critique of routines that is deeply informed by the work of Charles Sanders Peirce, the founder of American pragmatism, in particular his interlinked notion of inquiry and abduction. Simpson and Lorino (2016) provide an alternative theory of routines that addresses the limits of behaviourism (March and Simon, 1958) and practice-based approaches (Feldman and Pentland, 2003). Simpson and Lorino (2016) argue that the ostentative (i.e., the abstract, generalized idea of a routine) and performative (i.e., the routine in practice) views of routines, traditionally understood as a dualism, can be reconceptualized as a duality (i.e., as alternative ways of being and knowing which cannot be unified). Viewed in this way, the ostentative and performative aspects of routines can be used together, allowing researchers to question human action in organizations from competing perspectives.

Developing Dewey's ideas on inquiry, Elkjaer (2001; 2004) contends that organizational learning is experimental and played out as a 'what if' game which requires constant questioning. From this vantage point, questioning who we are and what are we doing in situations characterized by indeterminacy is constitutive of learning. A pragmatist perspective on organizational learning espoused by Elkjaer (2004) does not see organizational learning as the sum of all individual learning. Instead, attention is trained to organizing processes (order) and learning possibilities arising from tensions and conflict (disorder). 
In Critical Management Studies (CMS), questioning represents one of the core critical imagination practices that aim to develop radical alternatives while interrogating established theoretical traditions (Grey and Willmott, 2005). For example, Alvesson and Willmott (1992) discuss the idea of emancipation, of which a core feature is the practice of questioning. More than two decades later, Alvesson and Gabriel (2013) call for a move beyond formulaic research by making questioning a practice central to their argument. They argue that transgressions of formulaic argument, writing and thinking are not done in the name of mischievous dilettantism, but rather as exercises of legitimate critical questioning of boundaries and conventions.

Questioning is also central in two core propositions of the CMS approach, namely de-naturalization and reflexivity (Fournier and Grey, 2000), the former questioning the neutral façade of organizational life and the truthfulness of organizational knowledge, the latter problematizing our methods and ways of engagement with research matters. Interrogating the political significance of CMS, the authors ask whether it is more desirable to 'keep our critiques to ourselves and simply relish in the aesthetic pleasure that writing may provide us with...or should we champion the cause of the oppressed at the risk of further contributing to their domination by having our critique appropriated and translated into 'performative knowledge'? (2000, pp. 26-27). While accepting that such a tension cannot and will not be resolved satisfactorily for all CMS scholars, Fournier and Grey advocate re- 
imagining our relationship with practice, and highlight the importance of experience in how we question, think, create and advance the organization studies field.

Secondly, in regard to the role of questioning in (re)conceptualizing the organization studies field, organizations have been theorized by some authors as communities of diverse and at times divergent voices which construct multiple truths. Such voices enter a dialogic space (Lorino et al., 2011) to transform experience and achieve both individual and organizational goals. In the process, some voices are marginalized while others are elevated to a position of power and taken to be the truth. In this form of dialogism, which Bakhtin (1981) refers to as 'official monologism', there is asymmetry of power to the extent that active participation and questioning is systematically suppressed or deferred to existing rules, recurrent patterns and managerial procedures. Yet, despite attempts to render questioning futile, especially when practiced by actors who do not hold power, questioning can be used to construct alternative realities or challenge existing ones, albeit temporarily.

Castor (2009), for example, explores how questioning was used in a university setting to both construct and challenge a crisis situation. Leaders and administrators used questioning to frame events as problematic and legitimize certain courses of actions, while some members of staff used questioning strategies to challenge their leaders' argumentation. The US based university faced a budget crisis due to cuts from central government; the leaders of the university decided to cut down six departments 
and with the savings made create a reserve fund to pre-empt future problems. Members of staff challenged this course of action during debates in the senate by employing three questioning strategies: the first strategy was to appeal to another organizational entity to add weight to the question being posed; the second saw information being requested by asking either/or questions; while the last invoked comments on and evaluations of prior communications that supported a preferred point of view (a so-called metacommunicative commentary strategy). Castor (2009) argues that not only do questioning strategies construct and attempt to legitimize a particular version of reality but they contain a clear moral message about what is 'right' and 'wrong'.

Finally, methodological questioning is perhaps the most widespread practice in our field. A recent organization studies article by Sheep et al. (2016) employs organizational discourse analysis to ask a number of 'how' research questions, to gain a deeper understanding of perceived tensions and paradoxes within the context of a corporate spin off. Through methodological questioning the authors explore how employees name and experience tensions, how they problematize such tensions and deal with their consequences in practice. Researchers often explain the reasoning behind choosing certain research questions (e.g. Heinze et al., 2016; Moore, 2012; Malsch et al., 2012), the influence of the research context on the choice of questions (e.g. Luyckx and Janssens, 2016) or the questioning process itself (e.g. Riach et al., 2014; Drori and 
Honig, 2013; Bendl et al., 2014). Taking the above into account, where does this lead us in terms of knowledge?

\section{Questioning, knowledge and knowing}

At risk of stating the obvious, questioning has a fundamental role to play in generating knowledge but whether questioning is assigned a generative role in producing knowledge is open to debate, at least in pragmatist circles (Turnbull, 2008). For now, we enter a well-trodden site of debate concerning the contextual contingency of knowledge, the provisional nature of knowledge claims and the influence of questioning in shaping the various modalities and trajectories of organisational knowledge (Barley et al., 2018; Brown and Duguid, 2001; Tsoukas, 2002). One aspect of these debates concerns the influence of knowledge in sculpting the contours of the organisation studies field. For instance, Chia and Holt (2008) critique how business schools set epistemological parameters within which exploratory conversation, different conceptions of knowledge and questioning out of curiosity can be severely circumscribed. They contend that business students can simply ape what is required of them as 'professionals', 'rather than creatively engage with the problems of practice' $p$. 472). They advocate a more away from knowledge-by-representation (where management theories and concepts are understood to represent accurately managerial realities) to a form of knowledge that is grounded in the experience and practice of the demands of business life (p. 483-484). In so doing, we suggest they converse with a 
pragmatist perspective that focuses less on abstraction and theory, and more on the importance of concrete action and how this can help to solve real life problems. Indeed, within the epistemological restrictions Chia and Holt (2008) identify in business schools, the role of questioning is less likely to be creative and curious about the real demands of organisational life.

Similarly, Cook and Brown (1999) observe how organizational knowledge frequently relies on a single definition of the nature of knowledge as something that is possessed. They refer to this as the 'epistemology of possession' (1999, p. 381), held, modelled and analysed in the heads of individuals, which fails to account for 'the knowing found in individual and group practice'. (p. 381). They distinguish knowledge from knowing in how the latter is an 'epistemology of practice' (p. 381); specifically, how knowing is the 'epistemic work that is done as part of action or practice' (p. 387). In this frame, not all of what we know about the world can reside in knowledge, 'some also lies in our actions themselves' (p. 392). It is no coincidence that Cook and Brown (1999) draw inspiration from pragmatist philosophy, especially the writing of John Dewey. As they rightly submit, when it comes to addressing questions of what we know and how we know, Dewey places more emphasis on knowing as a part of concrete action. Knowing is not to be confused with tacit knowledge from this pragmatist perspective, since knowing is something we do not possess. In Cook and Brown (1999) 
the promise of a pragmatist perspective for treating knowing as an active process based in practice is outlined, and one in which questioning has an important role to play.

The work of Chia and Holt (2008) and Cook and Brown (1999) provide a bridge between questioning, organisational forms of knowledge and a pragmatist perspective on knowing that is rooted in practice. There are many pragmatist perspectives we might adopt to illustrate this (e.g. those derived from the writing of William James, Charles Sanders Peirce, George Herbert Mead, W. V. Quine, Hilary Putnam, Richard Rorty), but one we elect to explore in this essay is drawn from the work of John Dewey who conceptualizes questioning as a driver of the process of inquiry. To begin, we situate Dewey within a wider tradition of pragmatist thinking, in particular the work of Charles Peirce.

\section{Questioning and inquiry: a Deweyan approach}

Our point of entry into American pragmatism is via the classical tradition as exemplified in the work of Charles Sanders Peirce (1839-1914), William James (18421910) and John Dewey (1859-1952). This is not to say that the American pragmatist movement is defined only by the writings of these commentators. Other figures associated with early American pragmatism include George Herbert Mead and Josiah Royce. Furthermore, a number of neo-pragmatists have also had a hand in its development; notable among them is Richard Rorty. As such, American pragmatism is 
understood here as a complex and assorted collection of competing ideas, theories and perspectives. The plurality of American pragmatism and its potential relevance for the organization studies field has been discussed (Cook and Brown, 1999; Elkjaer and Simpson, 2011; Kelemen and Rumens, 2013; Lorino, 2018; Simpson, 2009). As such, one of our principal reasons for turning to American pragmatism and, expressly, the work of John Dewey is that scholars have credited Dewey for giving an enhanced status to questioning (Lorino, 2018; Meyer, 1988; Turnbull, 2008, 2014).

Before elaborating Dewey's contribution to questioning, it is important to start with Peirce's early description of inquiry, which was subsequently elaborated by Dewey. For Peirce, inquiry is triggered by doubt or uncertainty about the current situation, and it is resolved through an abductive process. This argument is set in motion in the essay 'The Fixation of Belief' in which Peirce writes 'The irritation of doubt causes a struggle to attain a state of belief. I shall term this struggle inquiry' (1877[1982], p. 67, emphasis in original). In Peirce's theory of inquiry, the 'sole object of inquiry is the settlement of opinion' (p. 67). Understood in this way, inquiry can sweep away 'various vague and erroneous conceptions of proof' (p. 67). Taking a swipe at those philosophers who insist we start an inquiry by 'questioning everything' (p. 68), Peirce points out that there 'must be a real and living doubt' (p. 68). Crucially, abduction is the first stage of inquiry and underwrites the logic of discovery insomuch as it is innovative in how it creates new ideas, relationships and possibilities for the 
future (Lorino, 2018). Indeed, Alvesson and Kärreman (2007) aver that the researcher should remain open to being surprised by new ideas and experiences, otherwise reasoning degenerates from 'disciplined abduction' to 'predetermined scientific methodological rhetoric'.

The point then is that abduction nurtures and cradles curiosity, allowing us to ask questions out of curiosity, even if these questions appear thoughtless and irreverent. In abduction, questioning is motored by a desire to imagine the future differently, and is thus oriented by a forward-looking perspective. Furthermore, questioning through abduction is an embodied experience because questions can be structured by emotions such as fear, and questioning can connect us with others. People's feelings and sensations are central to the process of questioning and its resolution. Inspired by this, Locke, Golden-Biddle and Feldman (2008) seek to broaden the meaning of methodology in organization studies by incorporating abduction so as to foster a process of discovery. The authors highlight the role of surprise and anomalies in provoking organization studies scholars to ask new questions, cultivate new ideas and ways of understanding the world. In a similar vein, Shepherd and Sutcliffe (2011) highlight the role of abduction in inductive top down theorising by arguing that an initial guess (hypothesis) is refined to enhance its potential contribution. Furthermore, the constant comparison of sensory and conceptual representations is said to facilitate the abductive process. 
Dewey's writing on questioning and inquiry is indebted to Peirce's initial thoughts on abduction. For Dewey, inquiry is directed towards specific ends, it is a process in which habits are mobilized and continually adapted to emerging situations. In that sense, there is a subtle difference between questioning and inquiry. The former, considered a tool, underwrites the latter, which is in Dewey's oeuvre, an important process by which actual outcomes are achieved. Inquiry is also a continuous and selfcorrecting set of activities. Dewey elaborates the ability of individuals to question through experience, considered to be the most important factor for achieving scientific progress and ultimately improving the human condition (Glassman, 2001). Dewey suggests that the human condition is realized in social interaction. Humans are born as social beings and it is through their experiences and relationships with the others, that they develop a sense of the self and a sense of individuality. Culture and history do not determine the life of the individual but they provide the necessary tools with which individuals can question and navigate certain social situations in search for their individuality. These tools (morals, ideals, values) are malleable and act as reference points, informing rather than predetermining human activities. When the tools no longer have pragmatic value, the individual can adapt or reject them in favour of more useful tools. To do so, the individual engages in a process of inquiry (Dewey, 1916[1980], 1938[1991]), which involves forward-looking questioning to confront and engage with issues that are not easily reconciled by current thinking/tools. 
As a continuator of the ancient tradition of questioning espoused by Socrates (Hadot, 2002), Dewey subjects questions to questioning, adapting them in order to make them relevant to collective practices. Dewey says: 'We inquire when we question; and we inquire when we seek for whatever will provide an answer to a question asked' (1938[1991], p.105). Therefore, 'thinking is inquiry, investigation, turning over, probing or delving into, so as to find something new or to see what is already known in a different light. In short, it is questioning' (Dewey, 1971, p. 265, emphasis in original). The importance of questioning in Dewey's pragmatism concerns its purpose, to bring about an answer in which the problem, the perplexity, no longer exists (Turnbull, 2008). Like Peirce (1877[1982]), doubt figures centrally in Dewey's conceptualization of a problem, as a state of doubt may incur perplexity and hesitation. Doubt arises because of surprises or unusual events that are difficult to comprehend and deal with. It comes into being when normal ways of doing things are disrupted and existing habits cannot explain what is going on and offer a solution. Dewey (1938[1991]) refers to such disruptions as indeterminate situations. When facing an indeterminate situation, the individual mobilizes existing habits and modifies them through questioning and experience, thus embarking on a process of inquiry. Inquiry is fundamentally local, social and experiential for Dewey. He writes: 'the local is the ultimate universal, as near an absolute as exists' (Dewey, 1927[1984]), p. 218) and we should accept 'life and experience in all its uncertainty, mystery, doubt, and half-knowledge' and, in turn, 'that 
experience upon itself to deepen and intensify its own qualities' (Dewey, 1934[1987], p. 41). In this formulation of doubt and inquiry, questioning is not required in unproblematic situations. What we can sense here is that questioning is a tool to provide an answer to a problem; moreover, it is the indeterminate situation that is the primary focus and independent of the questions we ask of it. In other words, Dewey does not ascribe a constitutive quality to questioning which has been subject to ongoing debate and revision (Turnbull, 2008, 2014).

Nevertheless, Dewey's take on questioning is highly relevant to organization studies. As we suggested earlier, organization studies scholars have highlighted the importance of the 'question' and to some extent of the process of questioning, but largely for purposes of intellectual critique, performativity and position building. Yet, if one was to engage in questioning simply out of curiosity, we believe different types of dialogue and methodologies would emerge along with more democratic forms of organizing.

\section{Implications for organization studies}

New methodologies and dialogues

Questioning enters into every area of organizational life in an intimate yet powerful way, shaping positions, power relations and revealing ideological backdrops. When questioning is carried out for the sake of curiosity and in a more democratic fashion, a 
variety of parties (both experts and non/experts) can potentially contribute more equally to imagining and building shared futures. For example, the dialogues between researchers and practitioners, between academics and policy makers, between marginalized groups and corporations/government can become more meaningful and productive. Such dialogues can help legitimize 'different ways of knowing' (Heron and Reason, 1997) which complement and enrich each other rather than competing for supremacy. Heron and Reason (1997) explain it thus. They maintain that the dominant way of knowing in organization studies is propositional which is abstract, conceptual and causality-based. However, experiential ways of knowing can emerge from a direct, immersive and participatory encounter with the situation at hand. These can help establish empathetic resonance within a world that is actively and creatively shaped through imagination and perception. Presentational ways of knowing are also linked to everyday experiences being typically represented in graphic, music, story, movement, dance, sculpture and other aesthetic forms, thus enriching textual forms of knowledge. Practical ways of knowing, which refer to knowing how to act in particular situations and how to solve particular problems, can potentially give non/experts a more equal voice in the inquiry process.

If such dialogues are to become more prevalent, new methodologies are needed to capture such different ways of knowing. There are various possibilities here, evident for example, in arts and performance based research methodologies (Purg and 
Sutherland, 2017). Pässilä, Oikarinen and Harmaakorpi (2015) illustrate the potential of research based theatre methodologies, which are a combination of participatory action research and applied drama and theatre practices, to bring together different ways of knowing and develop new dialogues between relevant parties (such as managers and customers), in the context of public health care in Finland. Their study demonstrates how research based theatre techniques can help to co-construct learning environments that encourage managers/professionals to question power dynamics and emotions embedded in their day to day organisational practices. One goal of this methodology is to encourage participants to put themselves in the positions of others (e.g. managers as customers and vice versa) using imaginary situations that are embedded in real experiences.

The links to Dewey can be observed as follows. According to Dewey (1933[2008]), we need to understand the complexity of different and sometimes competing positions and situations as triggers for learning. Arts and theatre-based methodologies have the potential to facilitate this (Purg and Sutherland, 2017). Additionally, they can provide opportunities for people's stories to be analysed and translated into performative theatrical scenes, where, for example, managers and employees can act out complex roles. Here, then, is potential for an indeterminate situation to be transformed into understanding through the questioning of the experiences related to the situation (Dewey, 1933[2008]). As in the case of Pässilä et al. 
(2015), the process of questioning appears to juxtapose the actual lived experiences of managers and customers and the imagined scenarios and related emotions and actions, in order to unearth assumptions which were deeply embedded and embodied in the organisation. Theatre-based research methodologies can occasion possibilities for practical reflexivity and the prospect of unsettling conventional practices and hierarchies (Cunliffe, 2002; Taylor and Ladkin, 2009), by accessing different types of knowledge and encouraging multiple ways of knowing. What participants hear, say, feel, do and experience in perplex situations represents data that cannot be captured by conventional research methodologies. Yet, it is this data that holds the capacity to surprise us, fuelling the imaginative act of creating new knowledge via abductive processes (Mantere and Ketoviki, 2013).

\section{Democratic forms of organizing}

Here, we suggest that questioning out of curiosity can engender questions that concern the organization of the social fabric of society and how we can organize in more democratic forms. On this understanding, Dewey's conceptualization of questioning can be situated within a wider vision of radical democracy wherein individuals take a principal role in the creative transformation of social activities. Notably, Turnbull (2008) reminds us that Dewey's notion of inquiry is democratic because it emphasizes deliberation through questioning and is oriented towards the problems of the public rather than the abstract problems of philosophy. Democracy is not necessarily political 
democracy for Dewey but a radically social and ethical phenomenon because it seeks transformation of the fabric of the community. Specifically, it is a way of life that emphasizes working with others, sharing with others and contributing positively to humanity. It requires cooperation amongst individuals not only to achieve goals but as a 'priceless addition to life' (Dewey, 1939[1988]), p. 342). Democratic inquiry helps to bring "conflicts out into the open where their special claims can be seen and appraised, where they can be discussed and judged in the light of more inclusive interests than are represented by any of them separately' (Dewey, 1939[2008], p. 56). It would, in Dewey's mind, enable curiosity and imagination to flourish unfettered by the demands of performative goal driven instrumentalism, this being a characteristic of knowledge production in organization studies (Chia and Holt, 2008).

In radical democracy, ongoing questioning of one's chosen courses of action and consequences is crucial. Dewey sees democracy as reciprocal and benefiting more than just a few in a given context. Reciprocity is about an equal opportunity to receive and to take from others. Collective democratic organizing acknowledges the unique contribution brought by each individual to the questioning process, rather than the group, class, or culture he/she belongs to. We suggest this questioning of one another is at the heart of democratically organized experience, but clearly it is one that we have to strive towards. It could be 'a way of life controlled by a working faith in the possibilities of human nature', relying on the belief that 'every human being, 
independent of the quality or range of his personal endowment, has the right to equal opportunity with every other person for development of whatever gifts he (sic) has' (Dewey, 1939[1988], p.342). Democratic organizing is based on the premise, 'that each individual shall have the opportunity for release, expression, fulfilment of his (sic) distinctive capacities, and that the outcome shall further the establishment of a fund of shared values' (Dewey, 1932 [2008], p. 350).

Academics have sounded a cautious note about Dewey's radical democracy construct, pointing out that the idea of a democracy wherein all people have active participation is not viable, not least because of the high level of consensus among individuals that would be required to hammer out and advance Dewey's goal of establishing shared values and interests (Westbrook, 2015). Similarly, Bernstein (2010) holds that Dewey is imprecise on the types of institution required for a radical democracy and, also, Dewey fails to appreciate fully that relations of power can generate colossal resistance to the types of radical reforms he proposes. These are valid misgivings but it would be wrong to think that Dewey was wholly naïve and out of touch with the fragility of democracy, and the obstacles confronting his vision of it. He was a pioneering social reformer who focused on serious problems encountered by ordinary people in and outside work.

His ideas on democracy can still excite us. As such, we suggest that organization 
studies scholars can derive inspiration from one influential organization, Hull-House in Chicago, a social settlement founded in 1889 by two activist and pragmatist philosophers Jane Addams and Ellen Gates Starr. Addams and Starr experimented with pragmatist ideas about democracy and social change having witnessed first-hand the punishing effects of industrialization on workers through low wages, dangerous working conditions and inadequate housing. Hull-House was established as a response to Addams's questioning of these social problems, summed up by Addams thus: 'The Settlement, then is an experimental effort to aid in the solution of the social and industrial problems which are engendered by the modern conditions of life in a great city' (Addams, 1910[1930], p. 125). In particular, Hull-House was a social and educational organization that sought to address the social ills experienced by the largely immigrant population of the local neighbourhood. As is clear from the quotation above, Addams employed a pragmatist approach which soon caught the attention of Dewey, with the two coming together through shared activism, philosophy and close friendship.

For both Addams and Dewey, democracy is viewed as a way of life, a way of living in co-operation and association with others. Hull-House became emblematic for its notion of democracy as a way of organizing and as a way of life. Crucial for organization studies scholars is the idea that both Addams and Dewey endorsed, that democratic organizing is premised on equality and living reciprocity. Furthermore, both Addams and Dewey equate co-operation and living reciprocity with embracing 
difference and understanding how human differences can benefit the self and others. As noted above, this was central to Dewey's scholarship on democracy, but also to Addams's writing, with the latter asserting that US citizens could learn a great deal from those who are marginalized. Her long standing association with immigrant labour reveals the passion with which Addams's advocated this: 'All members of the community are equally stupid in throwing away the immigrant revelation of social customs and inherited energy' (1907[2007], p. 41).

Hull-House underscores the value of questioning in organizing democratically since it relies on an experimental approach that requires individuals to question and relinquish preconceived belief systems. Indeed, Addams reflects on how she and others at Hull-House had to let go of 'preconceived ideas of what the neighbourhood ought to have, but to keep ourselves in readiness to modify and adapt our understandings as we discovered those things which the neighbourhood was ready to accept' (Addams, 1910[1930], p.132). Now, we do not present Hull house as a perfect example of democratic organizing, but, perhaps, there are valuable lessons organization studies scholars can draw from this mode of Chicago pragmatism. One is the necessity of questioning as a process of organizational transformation that can have a potentially positive impact on wider society, such as making a material difference to those people whose lives are on the edge of existence. Another relates to how organization studies scholars can attribute questioning out of curiosity a role in exploring how organization 
and organizing can be constituted and enacted differently, may be by drawing in the voices of others to engage in a profound questioning of established norms and orders. Certainly, the methodological approaches broadly outlined above could help to do this. Might we, perhaps, open up opportunities to work alongside managers and employees to foster more humane modes of organizing?

\section{Conclusion}

In this essay we have sought to elevate the importance of questioning in the organization studies field beyond typical concerns about critical imagination, conceptualizations and methodology. We have foregrounded extant efforts within the organization studies field to give questioning a more central concern within research and the discipline. Exciting debate on this topic, we have turned to the American pragmatism of John Dewey as a source of inspiration, not least because his theory of questioning establishes a link between questioning and inquiry. Or, as Turnbull writes, Dewey's theory of questioning is especially interesting because 'rarely have we questioned what it is to pose a question and to find a solution' $(2008,50)$.

Read, in part, as a reflective mode of thinking, Dewey's theory of questioning has all manner of implications for organization studies scholars, some of which we have introduced. If more organization studies scholars were to engage in questioning simply out of curiosity rather than for position building, we believe different types of dialogue 
and methodologies could emerge along with more democratic forms of organizing. Such dialogues would allow different ways of knowing to flourish and make possible for diverse parties to listen to each other's stories and experiences in a meaningful fashion. Equally, new methodologies could be promoted that not only ensure the coproduction of knowledge, but also can engender a 'giving back to the community' sensibility. Dewey's theory of questioning is also potentially important for democratic forms of organizing and organization, as it emphasizes deliberation that has in its sights the ordinary experience of individuals. In that regard, questioning could play a more active role as a form of inquiry into the organizational problems of people. Here, then, Dewey's writing stresses the significance of questioning in its own right but always nested within wider debates about experience, inquiry and knowledge.

To conclude, we hope this essay will stimulate future debate in the organization studies domain about questioning that relates it to wider pragmatic issues associated with organizing and organization. Dewey's pragmatism and theory of questioning is merely one strand of pragmatist thought that organization studies scholars can tap into. Indeed, we encourage organization studies scholars to mine the rich seam of pragmatism that accords questioning a central role, of which there is more to excavate in regard to Dewey's writing and other scholars who continue to keep the pragmatist tradition alive. 


\section{References}

Addams, J. (1910[1930]). Twenty years at Hull-House. New York: McMillan.

Addams, J. (1907[2007]). Newer Ideals of Peace. Repr., Urbana, IL: University of Illinois Press.

Alvesson, M., \& Gabriel, Y. (2013). Beyond formulaic research: In praise of greater diversity in organizational research and publication. Academy of Management Learning \& Education, 12, 245-263.

Alvesson, M., \& Kärreman, D. (2007). Constructing mystery: Empirical matters in theory development. Academy of Management Review, 32, 1265-1281.

Alvesson, M., \& Willmott, H. (1992). On the idea of emancipation in management and organization studies. Academy of Management Review, 17, 432-464.

Bakhtin, M. (1981). The dialogic imagination: Four essays. Holquist, M. (Ed.). Austin: University of Texas Press, Slavic Series.

Barley, W., Treem, J. W., \& Kuhn, T. (2018). Valuing multiple trajectories of knowledge: A critical review and agenda for knowledge management research. Academy of Management Annals, 12, 278-317.

Barratt, E. (2011). Re-reading C. Wright Mills, Organization, 18, 707-724.

Beck, U. (1992). Risk society: towards a new modernity. London: Sage.

Bendl, R., Danowits, M. A., \& Schmidt, A. (2014). Recalibrating management: Feminist activism to achieve equality in an evolving university. British Journal of Management, 25, 320-334.

Bernstein, R. (2010). The Pragmatic Turn. Cambridge: Polity Press.

Boudier, S. (1988). Toward a history of the question. In M. Meyer (Ed.), Questions and questioning (pp. 9-36). New York, USA: de Gruyter.

Brown, J. S., \& Duguid, P. (2001). Knowledge and organization: A social practice perspective. Organization Science, 12, 198-213.

Castor, T. (2009). 'It's just a process': questioning in the construction of a university crisis. Discourse Studies, 11, 179-197. 
Chia, R., \& Holt, R. (2008). The nature of knowledge in business schools. Academy of Management Learning and Education, 7, 471-486.

Cohen, M. (2007). Reading Dewey: reflections on the study of routine, Organization Studies, 28, 773-786.

Cook, S., \& Brown, J. S. (1999). Bridging epistemologies: The generative dance between organizational knowledge and organizational knowing. Organisation Science, $10,381-400$.

Cunliffe, A. (2002). Reflexive dialogical practice in management learning. Management Learning, 33, 35-61.

Derrida, J. (1967[1978]). Of Grammatology, trans. by Gayatri Chakravorty Spivak. Baltimore and London: Johns Hopkins University Press.

Dewey, J. (1916[1980]). Essays in experimental logic. In J. A. Boydston (Ed.), Middle Works 10 (pp. 320-369). Carbondale \& Edwardsville: Southern Illinois University Press.

Dewey, J. (1927[1984]). The public and its problems. In J. A. Boydston (Ed.), Later works 2 (pp. 235-351). Carbondale \& Edwardsville: Southern Illinois University Press.

Dewey, J. (1932[2008]). Ethics. In J. A. Boydston (Ed.), Later works 7 (pp. 1-510). Carbondale \& Edwardsville: Southern Illinois University Press.

Dewey, J. (1933[2008]). Essays and How we think. In J. A. Boydston (Ed.), Later works 8 (pp. 1-364). Carbondale \& Edwardsville: Southern Illinois University Press.

Dewey, J. (1934[1987]). Art as experience. In J. A. Boydston (Ed.), Later Works 10 (pp. 1-329), Carbondale \& Edwardsville: Southern Illinois University Press.

Dewey, J. (1938 [1991]). Logic: theory of inquiry. In J. A. Boydston (Ed.), Later works 12 (pp. 1-527). Carbondale \& Edwardsville: Southern Illinois University Press.

Dewey, J. (1939[1988]). Creative democracy - the task before us. In J. A. Boydston (Ed.), Later works 14 (pp. 225-231). Carbondale \& Edwardsville: Southern Illinois University Press.

Dewey, J. (1939[2008]). Freedom and Culture. In J. A. Boydston (Ed.), Later works 13 (pp. 63-173). Carbondale \& Edwardsville: Southern Illinois University Press. 
Dewey, J. (1971). How We Think: A Restatement of the Relation of Reflective Thinking to the Educative Process, 2nd Edn. Chicago, IL: Henry Regnery.

Dilon, J. T. (1982). The multidisciplinary study of questioning. Journal of Educational Psychology, 74, 147-165.

Drori, I., \& Honig, B. (2013). A process model of internal and external legitimacy. Organization Studies, 34, 345-376.

Elkjaer, B. (2001). The learning organization: An undelivered promise. Management Learning, 32, 437-452.

Elkjaer, B. (2004). Organizational learning: the third way. Management learning, 35, 419-434.

Elkjaer, B., \& Simpson, B. (2011). Pragmatism: A lived and living philosophy. What can it offer to contemporary organization theory? In H. Tsoukas \& R. Chia (Eds.), Philosophy and Organization Theory (Research in the Sociology of Organizations, Volume 32) (pp. 55-84). London: Emerald.

Feldman, M., \& Pentland, B. (2003). Reconceptualizing organizational routines as a source of flexibility and change. Administrative Science Quarterly, 48, 94-118.

Fournier, V., \& Grey, C. (2000). At the Critical Moment: Conditions and Prospects for Critical Management Studies. Human Relations, 53, 7-32.

Glassman, M. (2001). Dewey and Vygotsky: Society, experience, and inquiry in educational practice. Educational Researcher, 30, 3-14.

Grey, C., \& Willmott, H. (2005). Critical Management Studies: a Reader. New York, USA: Oxford University Press.

Hadot, P. (2002). What is Ancient Philosophy? Cambridge, Mass: Harvard University Press.

Heron, J., \& Reason, P. (1997). A participatory inquiry paradigm. Qualitative Inquiry, 3, 274-294.

Harrah, D. (1973). The logic of questions and its relevance to instructional science. Instructional Science, 1, 447-467.

Heinze, K., Sodestrom, S., \& Heinze, J. (2016). Translating institutional change to local communities: the role of liking organizations. Organization Studies, 37, 1141-1169. 
Kelemen, M., \& Rumens, N. (2013). American pragmatism and organization: issues and controversies. Aldershot: Gower.

Kilduff, M., \& Kelemen, M. (2001). The consolations of organization theory. British Journal of Management, 12, S55-S59.

Locke, K., Golden-Biddle, K., \& Feldman, M. S. (2008). Making doubt generative: rethinking the role of doubt in the research process. Organization Science, 19, 907-918.

Lorino, P. (2018). Pragmatism and organization studies. Oxford: Oxford University Press.

Lorino, P., Tricard, B., \& Clot, Y. (2011). Research methods for non-representational approaches to organizational complexity: the dialogical mediated inquiry, Organization Studies, 32, 769-801.

Luyckx, J., \& Janssens, M. (2016). Discursive Legitimation of a Contested Actor Over Time: The Multinational Corporation as a Historical Case (1964-2012). Organization Studies, 37, 1595-1619.

Malsch, B., Tremblay, M.-S., \& Gendron, Y. (2012). Sense-making in compensation committees: a cultural theory perspective. Organization Studies, 33, 389-421.

Mantere, S., \& Ketokivi , M. (2013). Reasoning in organization science. Academy of Management Review, 38, 70-89.

March, J., \& Simon, H. A. (1958). Organisation. New York: Wiley.

Meyert, M. (1988). Questions and questioning. New York, USA: de Gruyter.

Mills, W. (1959). The sociological imagination. New York: Oxford University Press.

Moore, G. (2012). Virtue in business: alliance boots and an empirical exploration of MacIntyre's conceptual framework. Organization Studies, 33, 363-387.

Pässilä, A., Oikarinen, T., \& Harmaakorpi, V. (2015). Collective voicing as a reflexive practice. Management Learning, 46, 67-86.

Peirce, C.S. (1877[1982]). The fixation of belief. In H.S. Thayer (Ed.), Pragmatism: the classic writings (pp. 61-78). Indianapolis, Indiana: Hacket.

Purg, D., \& Sutherland, I. (2017). Why art in management education? Questioning meaning. Academy of Management Review, 42, 382-396. 
Riach, K., Rumens, N., \& Tyler, M. (2014). Un/doing chrononormativity: negotiating ageing, gender and sexuality in organizational life. Organization Studies, 35, 16771698.

Shepherd, D. A., \& Sutcliffe, K. M. (2011). Inductive top-down theorizing: A source of new theories of organization. Academy of Management Review, 36, 361-380.

Sheep, M. L., Fairhurst, G. T., \& Khazanchi, S. (2016). Knots in the discourse of innovation: Investigating multiple tensions in a re-acquired spin off, Organization Studies, 38, 463-488.

Simpson, B. (2009). Pragmatism, Mead and the practice turn. Organization Studies, 30, 1329-1347.

Simpson, B., \& Lorino, P. (2016). Re-viewing routines through a Pragmatist lens. In J. Howard-Grenville, C. Rerup, A. Langley, \& H. Tsoukas (Eds.), Organizational Routines: How They Are Created, Maintained, and Changed. Perspectives on Process Organization Studies, vol. 6 (pp. 47-70). Oxford: Oxford University Press.

Taylor, S., \& Ladkin, D. (2009). Understanding arts-based methods in managerial development. Academy of Management Learning and Education, 8, 55-69.

Tsoukas, H. (2002). Knowledge based perspectives on organizations: Situated knowledge, novelty and communities of practice. Management Learning, 33, 419-426.

Turnbull, N. (2008). Dewey's philosophy of questioning: science, practical reason and democracy. History of the Human Sciences, 21, 49-75.

Turnbull, N. (2014). Michel Meyer's Problematology: Questioning and Society. London: Bloomsbury.

Westbrook, R. (2015). John Dewey and American democracy. Ithaca, USA: Cornell University Press. 